coloproctology $2018 \cdot 40: 357-363$ https://doi.org/10.1007/s00053-018-0281-5 Published online: 31 August 2018 (c) Springer Medizin Verlag $\mathrm{GmbH}$, ein Teil von Springer Nature 2018

CrossMark

\author{
V. Kahlke ${ }^{1,2} \cdot$ K. Feeser' $\cdot$ J. Jongen' $\cdot$ H. G. Peleikis' $\cdot$ R. A. Herbst ${ }^{3}$ \\ 'Department of Proctological Surgery Park-Klinik Kiel, Proctological Office Kiel, Kiel, Germany \\ ${ }^{2}$ School of Medicine, Christian-Albrechts-University, Kiel, Germany \\ ${ }^{3}$ Department of Dermatology and Allergology, HELIOS Klinikum Erfurt, Erfurt, Germany
}

\section{Perianal streptococcal dermatitis in adults}

\section{Is local therapy sufficient?}

Every coloproctologist knows patients with persisting perianal eczema despite adequate therapy of the underlying disease, e.g. rubber band ligation or even surgery for haemorrhoidal disease. In these cases, topical therapy with corticoids often leads to short-term relief only and one has to work up the differential diagnoses again: irritative-toxic, allergic, seborrheic and atopic eczema. Most frequently, irritative-toxic perianal eczema is associated with haemorrhoidal disease. Other causes for irritative-toxic perianal eczema are soiling due to, e.g., diarrhoea, fistulae, fissures, faecal incontinence, anal carcinoma or highgrade squamous intraepithelial lesions (HSIL). Furthermore, excess washing, use of soaps, detergents, disinfectants and wet wipes might cause irritativetoxic perianal eczema. In contrast, allergic eczema is a local allergic (type IV reaction) reaction often caused by overthe-counter creams, gels and mousses sold for the treatment of "haemorrhoids". In Germany, the use of perfumed wet toilet paper is frequently the cause of contact allergy. Atopic perianal eczema is often associated with other atopic diseases such as pollinosis, asthma and/or neurodermatitis. A rare cause for perianal eczema is seborrheic dermatitis, the pathophysiological understanding of which is still incomplete, although

Parts of the work were presented at the Annual Meeting of the German Society for Coloproctology, Munich, Germany 2015.

The German version of this article can be found under https://doi.org/10.1007/s00053018-0282-4.
Malassezia species triggering inflammatory and hyper-proliferative epidermal responses are suggested to play a role [1].

Recently, we demonstrated perianal streptococcal dermatitis (PSD) to occur in adult patients more often than reported to date and to be mainly caused by group B $\beta$-haemolysing Streptococci (GBBHS) [2]. This is in contrast to PSD in children, in which group A $\beta$-haemolysing Streptococci (GABHS) are predominant. This difference in groups of BHS in association with age also was observed by Sterbenc et al. [3]. While children with PSD can be cured in almost all cases by eradication of Streptococci with systemic antibiotic treatment, we demonstrated that in adults, a substantial percentage of patients require continuing or further treatment of their concomitant anorectal disease in addition to treatment of PSD to achieve freedom from symptoms. Although topical antibiotic therapy with, e.g., erythromycin or mupirocin has been advocated for paediatric PSD by some authors in the past [3-5], most dermatologists and paediatrics will treat PSD by oral antibiotics.

However, since systemic antibiotics carry the risk of potentially harmful side effects such as induction of systemic type I allergic reactions, Clostridiumdifficile-associated disease (CDAD) and antibiotic resistance, it was questioned whether topical therapy for this local perianal skin disease in adult PSD might be sufficient.
Retrospectively, a study was performed in adult PSD patients who were diagnosed and treated in an outpatient proctologic clinic. The main goal of the study was to assess treatment outcome: is topical therapy non-inferior to systemic antibiotic treatment? Additionally, we examined a "control" group of proctologic patients without eczema, pruritus ani or other clinical symptoms of PSD by microbiological examination of anal swabs to study the prevalence of Streptococci in this selected patient group.

\section{Patients and methods}

Starting in 2005, we performed perianal swabs for microbiological examination in adult patients who had persisting and symptomatic perianal erythema or eczema despite adequate anorectal treatment of anal disease such as haemorrhoids or anal fissures to detect BHS. After a study with oral antibiotic therapy of PSD [2], we changed our approach in February 2012 and started to treat these patients locally with a topical mupirocin $2 \%$ ointment (Infectopyoderm ${ }^{\circledR}$, Heppenheim, Germany). All patients diagnosed with PSD from February 2012 to March 2014 were identified $(n=129)$. Those patients treated locally were included in the study $(n=99)$ and data were analysed retrospectively, i.e. as a historical cohort analysis. Follow-up information was available for a median time of 12 months (0.2-24 months).

PSD symptoms were pruritus ani, erythema, eczema and sometimes skin lac- 


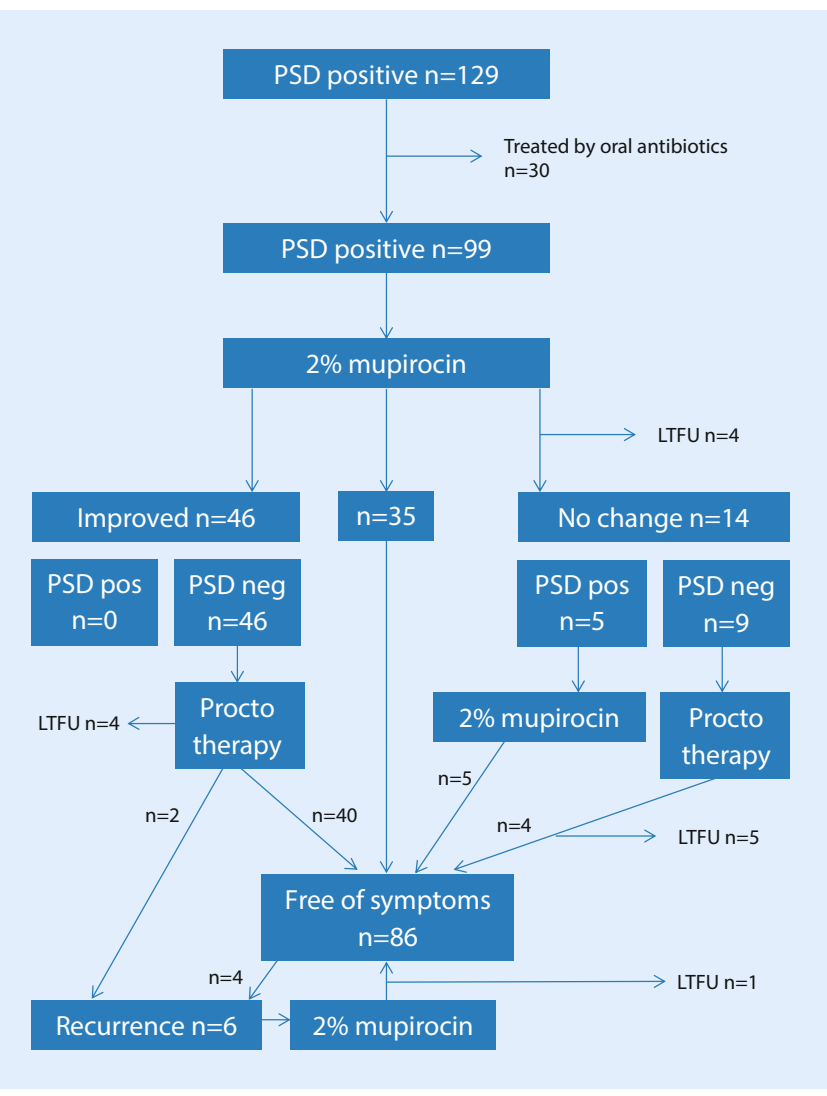

biological laboratory (Labor Staber, Dr. Ballies, Kiel, Germany). This protocol was approved by the institutional review committee and meets the guidelines of the governmental agency.

Data are presented as means or absolute numbers. They were compared using Student's t-test for age and Fisher's exact test for all distributions. Statistical significance was recognized at the $5 \%$ level $(P<0.05)$. Statistical evaluation was performed using the SSPS for Windows Software (version 11.5.1, IBM, Armonk, NY, USA).

\section{Results}

Fig. $1<$ Flowchart of the $n=129$ patients included into the study. PSD perianal streptococcal dermatitis, LTFU lost to follow-up, Procto therapy adequate proctological therapy eration. Most patients had been treated with 3-4 rubber band ligations and a topical $0.1 \%$ triamcinolone acetonide ointment for perianal eczema beforehand. If eczema and/or pruritus ani persisted, perianal swabs were performed and local ointment therapy with antimycotic and corticoid activity (flupredniden 21acetate $1 \mathrm{mg}$, miconazole nitrate $20 \mathrm{mg}$ ) was started. Microbiological examination was performed by a certified microbiological laboratory (Labor Staber, Dr. Ballies, Kiel, Germany) and focussed on Streptococcus species. The results of the swab examinations were classified semiquantitatively: none/negative, few, abundant or massive, and an antibiogram was performed routinely.

Swab-positive, symptomatic patients were defined as having PSD and treated with mupirocin $2 \%$ ointment twice daily for 14 days. A minimum of 4 days after the last topical ointment application, patients were seen in the office for physical examination and a control swab. According to clinical findings and self-reporting of the patients, they were classified into three groups graded according to the ex- tent of their remaining complaints: free of symptoms, improved symptoms or no change in symptoms. If patients were swab positive and had persistent symptoms, a second treatment course with mupirocin $2 \%$ ointment twice daily was started for another 14 days. Concomitant anorectal disease was treated as necessary. If patients were swab negative but still had symptoms, their underlying anorectal disease (typically haemorrhoids) was treated. If patients were swab positive but asymptomatic, no further treatment was performed (• Fig. 1). From February to March 2014, we examined 29 proctologic/surgical patients without perianal erythema or eczema or other PSD symptoms by microbiological swab to evaluate the prevalence of perianal colonisation with Streptococcus species in a "control" group (after informed consent). These patients had a cleansing enema as bowel preparation before they were operated on and the swab was collected after induction of the anaesthesia before the operation was started. All microbiological examinations were standardized and performed by the same certified micro-

\section{PSD patients}

From February 2012 until March 2014, 129 patients older than 17 years were diagnosed with PSD. Patients who had signs and symptoms of PSD and were positive for BHS on microbiological examination were intended to be treated (• Fig. 1). $N=30$ early patients $(23.3 \%)$ received oral treatment. These patients had to be excluded from further evaluation. Therefore, 99 patients (37 females, 62 males; mean age $47.9 \pm 13.7$ years; - Table 3) were included in the study and treatment with mupirocin (2\% ointment twice daily for 14 days) was initiated (- Fig. 1).

The Streptococcus group detected was not homogenous, but a majority of $67.7 \%$ belonged to group B BHS ( $\beta$ haemolytic Streptococcus, GBBHS), 13\% were group G Streptococcus (GGBHS), $7 \%$ group C Streptococcus (GCBHS) and only $4 \%$ group A Streptococcus (GABHS; - Table 1). In another $8 \%$, mixed groups of BHS or no defined group was found. There was no resistance to penicillin detected in the antibiogram. However, some resistances to other antibiotics were detected (data not shown).

In 75 patients $(75.7 \%)$, a control perianal swab was obtained a minimum of 4 days after the end of treatment. Of these, 69 (92\%) were negative. The remaining 6 patients $(8 \%)$ were positive for Streptococcus (2 massive group B, 1 massive group C, 3 abundant group B; • Table 2), of whom 1 patient was free of symptoms and did not require any further treat- 
coloproctology 2018 40:357-363 https://doi.org/10.1007/s00053-018-0281-5

(c) Springer Medizin Verlag GmbH, ein Teil von Springer Nature 2018

V. Kahlke · K. Feeser · J. Jongen · H. G. Peleikis · R. A. Herbst

Perianal streptococcal dermatitis in adults. Is local therapy sufficient?

\section{Abstract}

Objective. Perianal streptococcal dermatitis (PSD) in adults is still not well documented. After demonstrating systemic therapy to be efficient in adults-analogous to the therapeutic approach to the well-known disease in children - the question remained whether local therapy is also sufficient. We therefore treated adult PSD patients with mupirocin $2 \%$ locally.

Patients and methods. After diagnosis, patients were treated with mupirocin $2 \%$ locally for 2 weeks. Additional concomitant anorectal diseases were treated according to standard guidelines and the patients' clinical course was followed. A "control" group of patients without erythema, eczema or other symptoms of PSD was examined for the presence of $\beta$-haemolysing Streptococci (BHS) by perianal swab in order to investigate the prevalence of asymptomatic colonization.
Demographic and microbiological data were assessed and compared between and within treatment and control groups.

Results. 129 PSD patients $>17$ years (mean 48 years) were diagnosed between February 2012 and March 2014. In most cases, group B BHS (GBBHS) were found. In 99 patients, local treatment was administered for 14 days. In 69 of 75 patients (92\%) with a post-treatment swab, this swab was negative. Whereas 35 patients (35.4\%) had no further anorectal complaints, 57 patients $(57.6 \%)$ required continuing treatment of their concomitant anorectal disease. In the "control" group, GBBHS were found in $10 \%$. Conclusion. PSD should be included into differential diagnoses of refractory eczema in adult patients and is mainly caused by GBBHS. As a local skin infection, PSD can be treated effectively with mupirocin $2 \%$ locally.
However, pregnant women, immunodeficient patients as well as patients with systemic signs and symptoms of infection must be addressed differently and a systemic therapy remains standard in these special cases.

What does this paper add to the literature? This paper sheds new light on the treatment concept of perianal streptococcal dermatitis, up to now recognized as a disease of children. As a result of this paper, adult patients with persisting eczema despite proper anorectal treatment should be screened routinely for perianal streptococcal dermatitis and can be treated locally.

Keywords

Anus neoplasms · Eczema · Erythema · Pruritus ani $\cdot$ Streptococcus

\section{Perianale Streptokokkendermatitis bei Erwachsenen. Ist eine lokale Therapie ausreichend?}

\section{Zusammenfassung}

Ziel. Die perianale Streptokokkendermatitis (PSD) des Erwachsenen ist bis dato nicht gut dokumentiert. Nachdem die Effektivität der systemischen Therapie analog zum Vorgehen bei der in der Pädiatrie häufig vorkommenden PSD gezeigt wurde, stellte sich die Frage, ob auch eine ausschließlich lokale Therapie mit Mupirocin 2\% ausreichend ist. Dafür behandelten die Autoren erwachsene PSDPatienten lokal mit Mupirucin 2\%. Methoden. Der Diagnosestellung folgte die Einleitung einer 2-wöchigen lokalen Therapie mit Mupirocin 2\%. Zusätzlich zur PSD bestehende koloproktologische pathologische Befunde wurden leitliniengetreu therapiert. Der klinische Verlauf wurde entsprechend untersucht und dokumentiert. Zur Ermittlung der Prävalenz einer asymptomatischen Streptokokkenkolonisation im perianalen Bereich wurde eine „Kontrollgruppe" von Patienten ohne Erythem, Ekzem oder andere PSD-Beschwerden mittels eines perianalen Abstrichs untersucht. Demografische sowie mikrobiologische Daten wurden erhoben und ein Vergleich zwischen den Patientengruppen durchgeführt.

Ergebnisse. Bei insgesamt 129 Patienten >17 Jahre (Mittel: 48) wurde zwischen 2/2012 und 03/2014 die Diagnose PSD gestellt. In den meisten Fällen wurden im Abstrich $\beta$ hämolysierende Streptokokken der Gruppe B isoliert. Davon wurden 99 Patienten 14 Tage lokal behandelt. Bei 75 von innen wurde ein Kontrollabstrich nach der Therapie entnommen, davon waren 69 Abstriche negativ (92\%). Komplett beschwerdefrei waren 35 Patienten (35,4\%), 57 (57,6\%) dagegen benötigten noch weitere koloproktologische Therapie. In der Kontrollgruppe wurde in 10\% der Fälle eine asymptomatische Besiedlung mit $\beta$-hämolysierenden Streptokokken der Gruppe B gefunden.

Schlussfolgerung. Die PSD sollte standardmäßig in die möglichen Differenzialdiagnosen des therapierefraktären perianalen Ekzems bei Erwachsenen aufgenommen werden. Ursächlich sind zumeist $\beta$-hämolysierende Streptokokken der Gruppe B. Als lokale
Infektion der Haut kann die PSD effektiv mit Mupirucin 2\% therapiert werden. Bei entsprechenden Risikogruppen jedoch wie Schwangeren, immundefizienten Patienten oder Patienten mit Anzeichen einer systemischen Infektion sollte die orale systemische Therapie Standard bleiben. Neue Erkenntnisse dieser Arbeit. Diese Arbeit zeigt, dass die PSD einerseits fälschlicherweise als Erkrankung des Kindesalters gilt und sie stellt andererseits das bisherige Therapiekonzept der PSD in Frage. Als Ergebnis dieser Untersuchung sollte bei Erwachsenen, bei denen trotz adäquater proktologischer Behandlung ein perianales Ekzem persistiert, routinemäßig ein Abstrich zum Ausschluss einer PSD erfolgen. Im Falle eines postiven Abstriches ist eine lokale Therapie möglich.

Schlüsselwörter

Anusneoplasien · Ekzem · Erythem · Pruritus ani $\cdot$ Streptokokken 
Table 1 Number and distribution of the semi-quantitative classification of perianal swabs of 99 patients with clinical suspicion of perianal streptococcal dermatitis (PSD)

\begin{tabular}{|l|l|l|}
\hline Prevalence after culture & N & $\%$ \\
\hline None/negative & 0 & 0 \\
\hline Only a few bacteria & 2 & 2.0 \\
\hline Abundant growth & 38 & 38.4 \\
\hline Massive growth & 57 & 57.6 \\
\hline Few/abundant & 2 & 2.0 \\
\hline Total & 99 & 100 \\
\hline Lancefield group & & \\
\hline A & 4 & 4.0 \\
\hline B & 67 & 67.7 \\
\hline C & 7 & 7.1 \\
\hline G & 13 & 13.1 \\
\hline B/G & 4 & 4.0 \\
\hline B/C & 3 & 3.0 \\
\hline X (n.a.) & 1 & 1.0 \\
\hline n.a. not applicable & & \\
\hline
\end{tabular}

ment. The other 5 reported no change of symptoms (- Fig. 1).

After the first course of local antibiotic therapy, 35 patients (35.4\%) did not need any further treatment (• Table 2; - Fig. 1).

Improved symptoms were reported by 46 patients $(46.5 \%)$, but further anorectal treatment was needed. In most cases, patients were treated for haemorrhoidal disease, including 31 patients (67.4\%) treated by rubber band ligation. Three patients were lost to follow-up and one refused further therapy for unspecified reasons.

After this additional therapy, 40 patients had no further complaints and 2 patients who had recurrent PSD were successfully treated by mupirocin $2 \%$ ointment (• Fig. 1).

Another 14 patients (14.1\%) had no change of symptoms. Of these patients, $5(35.7 \%)$ with a positive control swab and persistent PSD were treated with mupirocin $2 \%$ ointment twice daily a second time and became free of symptoms either directly after this second course $(n=1)$ or after additional treatment of their haemorrhoids $(n=3)$. One patient was lost to follow-up (• Fig. 1).

Overall, $86(86.9 \%)$ of the initial 99 patients had no more complaints at the end of the treatment algorithm. In total,

Table 2 Number and distribution of the semi-quantitative classification of perianal swabs in

75 patients with perianal streptococcal dermatitis (PSD) after 2 weeks of treatment with mupirocin $2 \%$ ointment

\begin{tabular}{llll}
\hline Swab result & $\begin{array}{l}\text { Free of symptoms } \\
\mathbf{N = 3 5}\end{array}$ & $\begin{array}{l}\text { Improved } \\
\mathbf{N = 4 6}\end{array}$ & $\begin{array}{l}\text { No change } \\
\mathbf{N = 1 4}\end{array}$ \\
\hline None/negative & $24^{*}$ & $36^{*}$ & 9 \\
\hline Only a few bacteria & 0 & 0 & 0 \\
\hline Abundant growth & 0 & 0 & 3 \\
\hline Massive growth & 1 & 0 & 2 \\
\hline No swab & 10 & 10 & 0 \\
\hline Total $n=95$ ( $n=4$ LTFU) & 35 & 46 & 14 \\
\hline $\begin{array}{l}\text { LTFU lost to follow-up } \\
{ }^{*} p<0.05 \text { Fisher's exact test vs. no change }\end{array}$ & & \\
\hline
\end{tabular}

13 patients were lost to follow-up, 4 even before the control after the first treatment (- Fig. 1).

Interestingly, only 6 patients had recurrent PSD (6\%) between 1 and 6 months after the final treatment, 5 of whom could be cured by a second course of mupirocin $2 \%$ ointment treatment. One patient with persistent BHS received oral amoxicillin $1 \mathrm{~g} 3$ times per day for 2 weeks and became free of symptoms thereafter.

No differences with respect to sociodemographic data, group of BHS or treatment before or after PSD diagnosis could be detected when comparing the patient group healed after the first course of mupirocin $2 \%$ ointment with patients with no change or improved symptoms (- Table 3). However, patients free of symptoms after the first course had significantly less haemorrhoidal disease than patients with no change of symptoms and those with improved symptoms $(p<0.05)$. In contrast, patients with no change of symptoms were significantly more often diagnosed with anal fissures as a concomitant proctological disease than patients with freedom from or improvement of symptoms $(p<0.05)$.

Adverse side effects of the topical treatment were not reported by the patients.

\section{Controls}

During a 5-week period in 2014 (February to March), perianal swabs were obtained from 29 patients (9 females, 20 males; mean age $49.9 \pm 14.9$ years), who had neither signs nor symptoms of PSD (like pruritus ani, soreness, ery- thema or eczema). All patients came for proctological surgery (e.g. operation of anal fissure, fistulectomy, rectal advancement flap). Adequate diagnostic workup including colonoscopy if necessary had been performed before treatment. The age and gender distributions were not significantly different to those of the PSD group. Interestingly, a majority of 26 patients $(89.7 \%)$ without signs and symptoms of PSD were negative for Streptococcus, whereas only 3 patients were positive (10.3\%; - Table 4$)$. This was significantly $(p<0.05)$ less than in PSD patients (- Tables 1 and 4 ). None of these patients with a positive swab for BHS developed symptoms of PSD that necessitated antibiotic treatment during follow-up.

\section{Discussion}

In children, perianal streptococcal dermatitis (PSD) is a well-known cutaneous infection usually treated by oral antibiotics. This entity was first described by Amren in 1966 [7] in children, and has been investigated since then in several studies [8-10]. The clinical pattern is mainly defined by clearly marked perianal erythema. Itching, burning and soiling are typically reported [2-10]. The erythema can be associated with induration and even pain. Sometimes, fissures and even mucopurulent bloody soiling can occur [2]. In adults, however, PSD is more or less unknown, and up until 2013 [2], only a few case reports had been published [11-14]. In 2013, a series of 53 adult PSD patients was published [2]. These patients were treated system- 
Table 3 Sociodemographic data, pre-existing proctological therapy, concomitant diagnoses and microbiological data of 99 patients with perianal streptococcal dermatitis (PSD) stratified according to symptoms following the first therapy with mupirocin $2 \%$ ointment. Data presented as number (\%) or mean \pm standard deviation (age, BMI, number of RBL)

\begin{tabular}{l|l|l|l}
$\begin{array}{l}\text { Free of symp- } \\
\text { toms }\end{array}$ & $\begin{array}{l}\text { Improved } \\
N=35\end{array}$ & $\begin{array}{l}\text { No change } \\
N=14\end{array}$ & $\begin{array}{l}\text { LTFU } \\
N=4\end{array}$ \\
\hline
\end{tabular}

\section{Sociodemographic}

\begin{tabular}{|c|c|c|c|c|}
\hline Women & $15(42.9)$ & $17(41.5)$ & $4(28.6)$ & $1(25)$ \\
\hline Men & $20(57.1)$ & $29(63)$ & $10(71.4)$ & $3(75)$ \\
\hline Age (women) & $48.7 \pm 12.4$ & $52.4 \pm 16.4$ & $47.7 \pm 10.3$ & 47.3 \\
\hline Age (men) & $44.8 \pm 14.7$ & $48.5 \pm 11.5$ & $47.2 \pm 13.9$ & $37.1 \pm 11.9$ \\
\hline BMI (women) & $25.0 \pm 3.3$ & $24.7 \pm 3.3$ & $26.6 \pm 2.4$ & 18.6 \\
\hline BMI (men) & $25.8 \pm 4.6$ & $25.2 \pm 2.8$ & $26.0 \pm 2.7$ & $25.2 \pm 4.7$ \\
\hline \multicolumn{5}{|l|}{ Lancefield group } \\
\hline A & $2(5.7)$ & $2(4.3)$ & 0 & 0 \\
\hline B & $24(68.6)$ & $32(69.6)$ & $9(64.3)$ & $2(50)$ \\
\hline C & $2(5.7)$ & $1(2.1)$ & $3(21.4)$ & $1(25)$ \\
\hline G & $4(11.4)$ & $7(15.2)$ & $1(7.1)$ & $1(25)$ \\
\hline$B / G$ & $3(8.6)$ & 0 & 0 & 0 \\
\hline$B / C$ & 0 & $3(6.5)$ & $1(7.1)$ & 0 \\
\hline X (n.a.) & 0 & $1(2.1)$ & 0 & 0 \\
\hline \multicolumn{5}{|l|}{ Pre-existing proctologic therapy } \\
\hline $\mathrm{RBL}$ & $17(48.6)$ & $32(69.6)$ & $9(64.3)$ & $1(25)$ \\
\hline $\begin{array}{l}\text { No. of RBL before PSD diag- } \\
\text { nosis }\end{array}$ & $3.5 \pm 3.9$ & $4.7 \pm 4.0$ & $4.4 \pm 4.5$ & 4 \\
\hline Anal fissure & $5(14.3)$ & $7(15.2)$ & $5(35.7)$ & 0 \\
\hline Coloproctological operation & $4(11.4)$ & $5(10.8)$ & $2(14.3)$ & $1(25)$ \\
\hline PSD with systemic treatment & $2(5.7)$ & $7(15.2)$ & $4(28.6)$ & 0 \\
\hline No treatment & $13(37.1)$ & $10(21.7)$ & $4(28.6)$ & $2(50)$ \\
\hline \multicolumn{5}{|l|}{ Concomitant diagnosis } \\
\hline Haemorrhoids & $29(82.9)^{*}$ & $45(97.8)$ & $14(100)$ & $4(100)$ \\
\hline Pruritus ani & $35(100)$ & 45 (97.8) & $14(100)$ & $4(100)$ \\
\hline Anal fissure & $2(5.7)^{* *}$ & $2(4.4)^{* *}$ & $4(28.6)$ & 0 \\
\hline Psoriasis & $3(8.5)$ & $8(17.4)$ & $2(14.3)$ & $1(25)$ \\
\hline Neurodermitis & $1(2.9)$ & 0 & 0 & 0 \\
\hline HPV infection & $2(5.7)$ & $2(4.4)$ & 0 & 0 \\
\hline Post-PSD RBL & 0 & $31(67.4)$ & $6(42.9)$ & 0 \\
\hline No. of RBL & 0 & $2.1 \pm 2.1$ & $1.2 \pm 2.1$ & 0 \\
\hline
\end{tabular}

ically with antibiotics analogous to paediatric PSD patients. In contrast to children, in whom PSD was mostly caused by GABHS, adult PSD was associated with GBBHS. This finding was confirmed by Sterbenc et al. [3]. In paediatric PSD patients, eradication by systemic antibiotics lead to an almost $100 \%$ cure rate. In contrast, only $42 \%$ of adult patients could cation of BHS infection solves their problem.

This study was started to explore whether topical treatment in adults is as effective as oral treatment but without the possible side effects like CDAD, development of bacterial resistance and allergic reactions etc. Topical mupirocin $2 \%$ ointment was chosen because of its effectivity against Streptococci (among others). The main limitation of the present study is its design as a historical cohort analysis, i.e. a retrospective design with a possible bias. However, to the best of our knowledge, this is the largest cohort of adult PSD patients published to date. This patient group was comparable with the one that was treated with enteral antibiotics [2].

In both cohorts, GBBHS was the cause of PSD in the majority of cases. GGBHS was cultured second most frequently and has also been described in other reports on adult PSD [3, 12, 14, 15].

After the first topical treatment, 35\% of the patients were free of symptoms. The eradication rate after topical antibiotic therapy was even better than with oral treatment (92 vs. $84 \%$ ). However, in both studies, more than $50 \%$ of the patients needed further anorectal treatment. One reason might be the fact that adults often have underlying anorectal lesions like haemorrhoids, anal fissures, anal skin tags, etc., which lead to symptoms themselves and treatment thereof needs to be completed for cure. In the present study, the group with no change of symptoms included $28 \%$ of patients with an anal fissure as a concomitant disease.

On the other hand, underlying lesions might also be pathophysiologically fundamental to paving the way for BHS colonisation and the development of PSD. Constant soiling, e.g. due to haemorrhoidal disease, might disturb the perianal skin microbiome, effecting its composition and thereby reducing the defence against infection. In addition, it also impairs the skin barrier in general. This may also explain recurrence after treatment. Recurrence rates in both studies were comparable (6\% after topical treatment vs. $4 \%$ after oral therapy [2]). On the other hand, local treatment with 
Table 4 Number and distribution of the semi-quantitative classification of perianal swabs in 29 surgical patients without clinical suspicion of perianal streptococcal dermatitis (PSD) $=$ control group

\begin{tabular}{|l|l|l|l|}
\hline Swab result & No & $\%$ & Lancefield group \\
\hline None/negative & 26 & 89.7 & - \\
\hline Few & 2 & 6.9 & $\mathrm{~B} / \mathrm{C} ; \mathrm{C}$ \\
\hline Abundant & 0 & 0 & - \\
\hline Massive & 1 & 3.5 & $\mathrm{~B}$ \\
\hline
\end{tabular}

a cream or ointment may help to repair an impaired skin barrier and thereby support the antibiotic action.

The question remains as what triggers the transformation from asymptomatic colonisation with Streptococcus to infection and outbreak of clinically symptomatic PSD.

The pathogenesis in children may be different, beginning with a microbiome that differs in its composition from adults, with possibly longer stool-skin contact and more anal-digital-oral interchange. Reported recurrence rates in children range from 1 [16] up to 32.4 [17] or even $39 \%$ [18], and there is general agreement that therapy should be continued for a sufficiently long period and control swabs should be taken to confirm eradication.

Although the study was performed retrospectively, we adhere to the topical mupirocin regime of adult PSD and have also started the same regime in paediatric cases of PSD.

Excluded from this approach are people with a special medical history and related complication risks: immunodeficiency, for example. Pregnant women are also treated with oral antibiotics, as the anogenital region is a well-known reservoir for Streptococci, especially for GBBHS, and this might cause serious septic disease in neonates after vaginal delivery in women with anorectal colonisation by GBBHS [19]. In addition, patients with systemic signs and symptoms of an infection should be treated systemically.

Streptococci might, as mentioned above, be part of the transient skin flora of the anal region (asymptomatic colonisation). In the control group, only $10 \%$ were positive for BHS. This is slightly in contrast to our former study [2] showing $34 \%$ positive for BHS. The difference can be explained by the bowel preparation and the cleaning procedures of the anal region that patients underwent before they were operated on and the swab was collected. This might have led to a reduction of the bacterial population in the swabbed region. However, on the other hand, there are studies of pregnant women where a positive perianal swab for BHS was obtained in 2.5 up to $25 \%$, showing the same range of variation as in our population [19-23].

\section{Conclusion}

Anorectal lesions in adults can be associated with PSD. If patients have treatmentresistant perianal eczema, PSD should be taken into account and a perianal swab should be taken. There will be no healing if either the underlying disease or the PSD is insufficiently treated. Therefore, if the swab is positive for BHS, local treatment with mupirocin $2 \%$ ointment should be started to eradicate Streptococci. In general, topical treatment is an efficient and safe treatment for this local skin infection of the perianal region.

\section{Corresponding address}

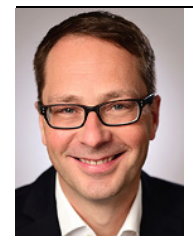

V. Kahlke, MD, PhD Department of Proctological Surgery Park-Klinik Kiel, Proctological Office Kiel Beselerallee 67, 24105 Kiel, Germany info@proktologie-kiel.de

Acknowledgements. We would like to thank Dr. Ballies (Labor Staber, Kiel) for the microbiological work-up of the swaps from both the patients and the control group. We also thank our "ladies" in the office for their unconditional support for this study.

Funding. Supported by departmental funds.

\section{Compliance with ethical guidelines}

Conflict of interest. V. Kahlke: Consultant for: Medtronic Inc., USA; Lecture fees: Falk Foundation, Freiburg, Germany. J. Jongen: Lecture fees: Dr. Kade, Berlin, Germany; Ethicon, Norderstedt, Germany; Falk Foundation, Freiburg, Germany; Ovesco Endoscopy AG, Tübingen, Germany. K. Feeser, H.G. Peleikis and R.A. Herbst declare that they have no competing interests.

This article does not contain any studies with human participants or animals performed by any of the authors.

\section{References}

1. Prohić A, Jovović Sadiković T, KuskunovićVlahovljak S, Baljić R (2016) Distribution of Malassezia species in patients with different dermatological disorders and healthy individuals. Acta Dermatovenerol Croat 24:274-281

2. Kahlke V, Jongen J, Peleikis HG, Herbst RA (2013) Perianal streptococcal dermatitis in adults: its association with pruritic anorectal diseases is mainly caused by group B Streptococci. Colorectal Dis 15:602-607

3. Šterbenc A, Seme K, Lah LL, Točkova O, Kamhi Trop T, Švent-Kučina N, Pirš M (2016) Microbiological characteristics of perianal streptococcal dermatitis: a retrospective study of 105 patients in a 10-year period. Acta Dermatovenerol Alp Pannonica Adriat 25:73-76

4. Medina S, Gómez Ml, de Misa RF, Ledo A (1992) Perianal streptococcal cellulitis: treatment with topical mupirocin. Dermatology (Basel) 185:219

5. Paradisi M, Cianchini G, Angelo C, Conti G, Puddu $P$ (1993) Efficacy of topical erythromycin in treatment of perianal streptococcal dermatitis. Pediatr Dermatol 10:297-298

6. Fischer G, Rogers M (2000) Vulvar disease in children: a clinical audit of 130 cases. Pediatr Dermatol 17:1-6

7. Amren DP, Anderson AS, Wannamaker LW (1966) Perianal cellulitis associated with group $A$ streptococci. Am J Dis Child 112:546-552

8. Mogielnicki NP, Schwartzman JD, Elliott JA (2000) Perineal group A streptococcal disease in a pediatric practice. Pediatrics 106:276-281

9. Landolt M, Heininger U (2005) Prevalence of perianal streptococcal dermatitis in children and adolescents. Praxis (Bern 1994) 94:1467-1471

10. Wright JE, Butt HL (1994) Perianal infection with beta haemolytic streptococcus. Arch Dis Child 70:145-146

11. Neri I, Bardazzi F, Marzaduri S, Patrizi A (1996) Perianal streptococcal dermatitis in adults. $\mathrm{Br} \mathrm{J}$ Dermatol 135:796-798

12. Scheiba N, Hartschuh W (2011) Perianal streptococcal dermatitis caused by $\beta$-hemolytic group $\mathrm{G}$ streptococci in two adults. Hautarzt 62:131-133

13. Bafounta ML, Bloch $P$, Kernbaum $S$, Saiag $P$ (1998) Group A beta-hemolytic Streptococcus: an unusual etiology of perianal dermatitis in an adult? Ann Dermatol Venereol 125:902-904

14. Abdolrasouli A, Hemmati Y, Amin A, Roushan A, Butler I (2012) Lancefield group G Streptococcus dysgalactiae subsp. equisimilis: an unusual aetiology of perianal streptococcal dermatitis 
acquired from heterosexual oral-anal intercourse. Int J Std Aids 23:911-912

15. Kallini JR, Cohen PR (2013) Perianal and periumbilical dermatitis: Report of a woman with group $G$ streptococcal infection and review of perianal and periumbilical dermatoses. Dermatol Online J 15(19):3

16. Jongen J, Eberstein A, Peleikis HG, Kahlke V, Herbst RA (2008) Perianal streptococcal dermatitis: an important differential diagnosis in pediatric patients. Dis Colon Rectum 51:584-587

17. Teillac-Hamel D, de Prost $Y$ (1995) Treatment of atopic dermatitis. Arch Pediatr 2(9):883-885. https://doi.org/10.1016/0929-693x(96)81268-1 (Traitement de la dermatite atopique)

18. Kokx NP, Comstock JA, Facklam RR (1987) Streptococcal perianal disease in children. Pediatrics 80:659-663

19. RocchettiTT,MarconiC, RallVL, Borges VT, Corrente JE, da Silva MG (2011) Group B streptococci colonization in pregnant women: risk factors and evaluation of the vaginal flora. Arch Gynecol Obstet 283:717-721

20. Hiller JE, McDonald HM, Darbyshire $P$, Crowther CA (2005) Antenatal screening for Group B Streptococcus: a diagnostic cohort study. BMC Pregnancy Childbirth 22(5):12

21. Joshi AK, Chen Cl, Turnell RW (1987) Prevalence and significance of group BStreptococcus in a large obstetric population. CMAJ 137:209-211

22. Sinha A, Russell LB, Tomczyk S, Verani JR, Schrag SJ, Berkley JA, Mohammed M, Sigauque B, Kim SY (2016) GBS vaccine cost-effectiveness analysis in sub-saharan africa working group. Disease burden of group B streptococcus among infants in subsaharan africa: a systematic literature review and Meta-analysis. Pediatr Infect Dis J 35:933-942

23. Linhares JJ, Cavalcante Neto PG, Vasconcelos JL, Saraiva Tde V, Ribeiro AM, Siqueira TM, Rocha FR (2011) Prevalence of the colonization by Streptococcus agalactiae in pregnant women from a maternity in Ceará, Brazil, correlating with perinatal outcomes. Rev Bras Ginecol Obstet 33:395-400

\section{$\Gamma$ \\ Lesen Sie Ihre Zeitschrift online auf SpringerMedizin.de}

SpringerMedizin.de bietet Ihnen Zugang zu allen elektronisch verfügbaren Ausgaben und dem CME-Angebot lhrer Zeitschrift - unabhängig davon, seit wann Sie die Zeitschrift abonniert haben.

So einfach erhalten Sie Zugang zum Online-Archiv:

$>$ Registrieren Sie sich einmalig auf www.springermedizin.de/register

Geben Sie dabei Ihre Einheitliche Fortbildungsnummer (EFN) an.

> Ihr Benutzername entspricht Ihrer E-Mail-Adresse, Ihr Passwort können Sie frei wählen und später jederzeit unter "Mein Profil“ ändern.

Falls Sie bereits ein (Print-) Abonnement bei uns haben, geben Sie bei der Registrierung die Lieferadresse Ihrer Zeitschrift an. Damit wird Ihr Abo-Zugang auf springermedizin.de freigeschaltet.

Sind Sie bereits bei SpringerMedizin.de registriert?

Dann wird Ihr Zeitschriftenabonnement automatisch Ihrem Online-Nutzerkonto hinzugefügt. Sollten die Angaben Ihres Online-Accounts nicht eindeutig mit den Angaben Ihres Zeitschriften-Abonnements übereinstimmen, kann die Zuordnung nicht sicher erfolgen. In diesem Fall und bei allen anderen Fragen zum Online-Zugang kontaktieren Sie bitte unseren Kundenservice unter: Kundenservice@springermedizin.de

Telefonisch erreichen Sie die Hotline montags bis freitags von 9.00 bis $17.00 \mathrm{Uhr}$ kostenfrei unter 0800-77 80777 sowie gebührenpflichtig aus dem Ausland unter +4930884293600. 